ro3 Putnam, J. D. Report on the insects collected by Captain Jones's expedition to northwestern Wyoming in 1873 . (Proc. Davenp. acad. nat. sci., I876, v. I, p. I87I9I.)

44 identified and $\mathrm{I}$ unidentified species of Coleoptera are listed from Green River Basin : Fort Bridger; 38 identified and 2 unidentified from Wind River Basin: Stinkingwater River; and 21 species from Yellowstone National Park.
I04 Putnam, J. D. Report on the insects collected in the vicinity of Spring Lake Villa, Utah Co., Utah, during the summer of 1875 . (Proc. Davenp. acad. nat. sci., I876, v. I, p. I93-205.)

From the Mount Nebo alpine region 52 determined and 3 undetermined species of Coleoptera are listed from Salt mud flat near Utah Lake 38 determined and $\mathrm{x}$ undetermined and from the Sage brush region 105 determined and 7 undetermined.

\title{
HETEROPACHA RILEYANA.
}

\author{
BY CAROLINE G. SOULE, BROOKLINE, MASS.
}

Éggs laid July I, I89I, at Columbus, Ohio.

Eggs globular, opaque white mottled with dark green, a dot of green on top.

July I I, I.3O P.M., they hatched.

roung larvae I-8 inch long. Head very large, round, horn-colored mottled with brown. Body gray, striped longitudinally with dark brown on each side of the dorsum. I th segment black on top. Body covered with short, gray hairs. Feet and props gray. Anal props very slender and spread far apart. The body tapered from head to anal end. The larvae moved very fast, and were flat instead of cylindrical.

Three days later they had changed somewhat in color, the head being dull white barred with brown; the body dull white on dorsum with a black dorsal line, and a black dash on each side of this line. From each dash arose a small, dark wart with short spreading hairs. The sides were dark gray with a dull white line from $5^{\text {th }}$ segment to anal props. The hairs were most abundant over the head and feet, and were grayish. Each segment had a few warts, with sparse short hairs.

July i6. First moult. Head darker, hairy, mottled with white, the dark and white lines extending back over the first segment, the body, as before, giving the effect of black and white stripes. The tapering from head to anus was very noticeable, as was the flat, leech-like shape. The hairs were long over the feet, shorter along the stigmatal line, and very short on the sides and dorsum.

July ig. Second moult. Length I-2 inch. Head dark barred with white hairs. Body tan-colored on dorsum with two black dashes on each segment. Lateral and stigmatal lines nearly black. A black patch on top of the IIth segment. Feet and props dark gray. Hairs sparse and short except over feet and props, where they seemed to "fringe" the whole edge of the larva.

July 23. Third moult. Length one inch or a trifle less. Head black with two short yellow lines on top, and a yellow spot near the mouth, hairy. Body brown on dorsum, yellow between the segments, with black dashes. Two yellow dashes on 12 th segment. No black patch on IIth segment. Lateral and stigmatal lines of black and pale brown. Feet and props dark, overhung by long gray hairs in tufts. Very short hairs on the dorsum, and very sparse.

July 27 th. Fourth moult. I I-2 inches long. Head as before. The body was marked with brown, black, tan, and yellow or white, in a sort of "oil-cloth pattern" very difficult to describe, and varying with individuals. The dorsal hairs were unnoticeable without a lens, but the stigmatal fringe 
remained, and the general look of the larvae was like Tolype laricis except in color.

The larvae moved very rapidly, and when at rest lay closely adhering to the twig of honey-locust, so flat as to be inconspicuous. The cast skins seemed to be thicker and more leathery than those of most Bombycid larvae. These larvae drank less than most that I have reared.
Cocoon. Aug. 5. The first one spun a thin parchment-like cocoon, 3-4 of an inch long, oval, slender, of a red-brown color mottled with gray. It spun very slowly, taking over two days.

Pupa. Aug. II. The pupa was formed. It was 3-4 of an inch long, slender, dark brown, and had a white chalky substance all over it, which fell off when the pupa was touched.

\title{
PREPARATORY STAGES OF PHEOSIA DIMIDIATA H.S.
}

\author{
BY HARRISON G. DYAR.
}

Pheosia dimidiata Herrich-Schäffer. I854-Herr-Sch., Saml. ausser. schmett., p. 66, fig. $5{ }^{1} 5$, Drymonia.

I882-Grote, New check list, p. I9, Pheosia.

rimosa Packard.

I864-Pack., Proc. ent. soc. Phil., v. 3, p. 358 .

I 877 -Lintner, Ent. cont., iv. p. $76=$ dictaea.

I878-Tepper, Bull. Brook. ent. soc., v. $\mathrm{I}, s p$. dist.

I882-Goodhue, Can. ent. v. I4, p. 73.

I890-Packard, 5 th rept. U.S. ent. comm.,

p. $455, s p$. dist.

I89I-Dyar, Psyche, v. 6, p. I28.

californica Stretch.

I873-Stretch, Zyg. \& Bomb. N. A. v. I,

p. I16, pl. 4, fig. 5, larva, pl. io. Notodonta.

I877-Lintner, Ent. cont., iv. p. 76, pr. syn.

Egg. Hemispherical, the base flat, smooth, sublustrous, white. Under the microscope it appears closely covered with dense, very small, rounded granulations, which are of about uniform size, but fused into a small white spot at the micropyle. Diameter I.I mm. Laid singly, usually on the under side of the leaves of its food-plants. The larva hatches by eating a hole in the side of the egg, but leaves the rest of the shell intact.

First stage. Head slightly bilobed, black and shiny; labrum white; a few hairs; width $.6 \mathrm{~mm}$. Joint $\mathrm{I} 2$ is slightly enlarged dorsally, otherwise the body is uniformly cylindrical. There is no trace of the caudal horn so conspicuous in the last stage. Body pale white; cervical shield, anal plate and thoracic feet black. From the minute elevated dots arise blackish hairs which are apparently not glandular but pointed at tip. A subventral broken blackish band which later changes to purple. Legs normal, the anal pair not elevated, all black outwardly. Near the end of the stage a purplish patch appears under the skin on joint 12 dorsally in the location of the piliferous dots of row I, indicating the origin of the caudal horn. The piliferous dots of row I are close together on joint 12 , more normal on joint $\mathrm{II}$ and almost in line with those of row 2 on the anterior segments. Row 3 are large, lateral; rows 4 and 5 small; row 6 distinguishable only on the legless segments and row 7 normal, on the venter of the apodal joints. In the latter 

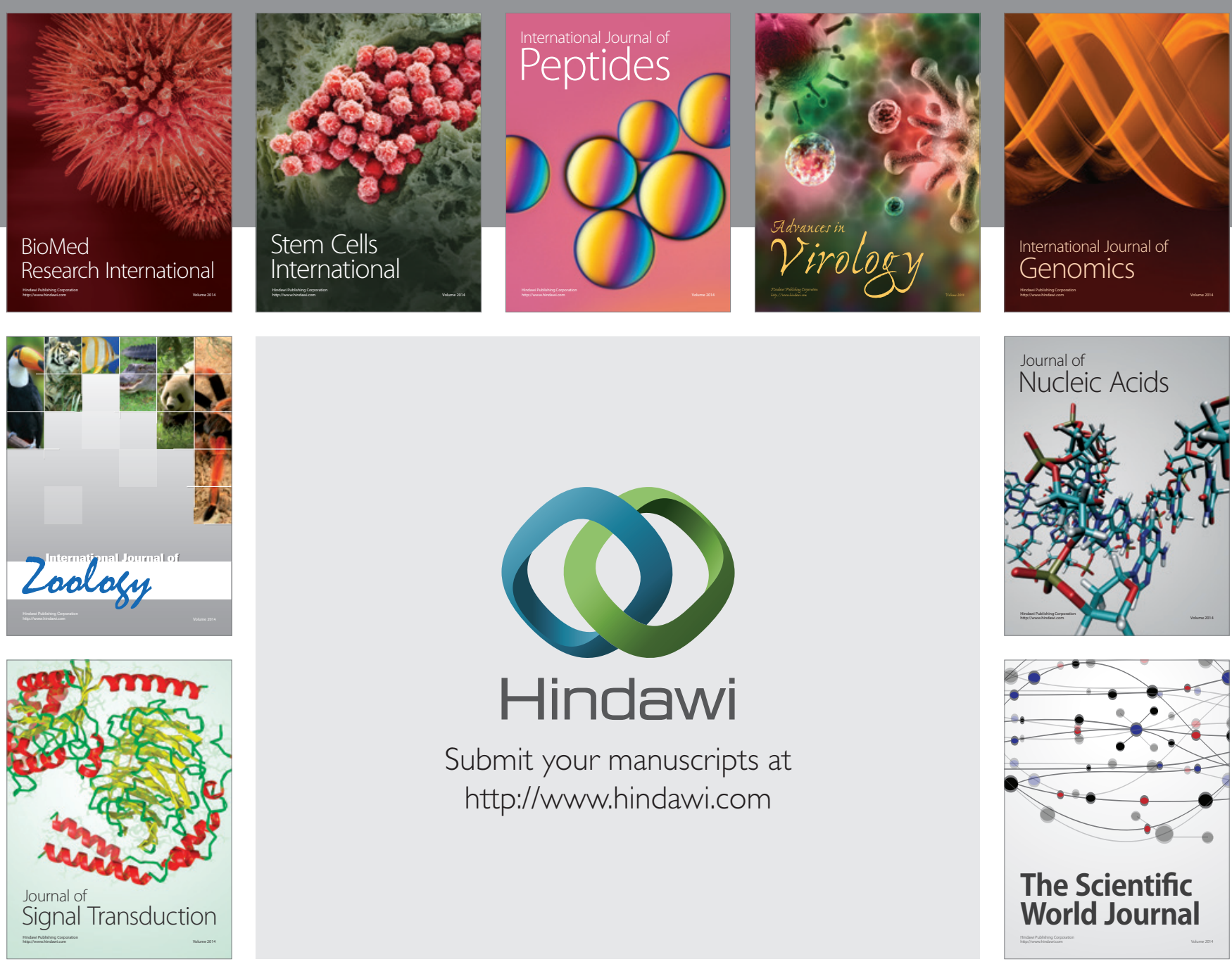

Submit your manuscripts at

http://www.hindawi.com
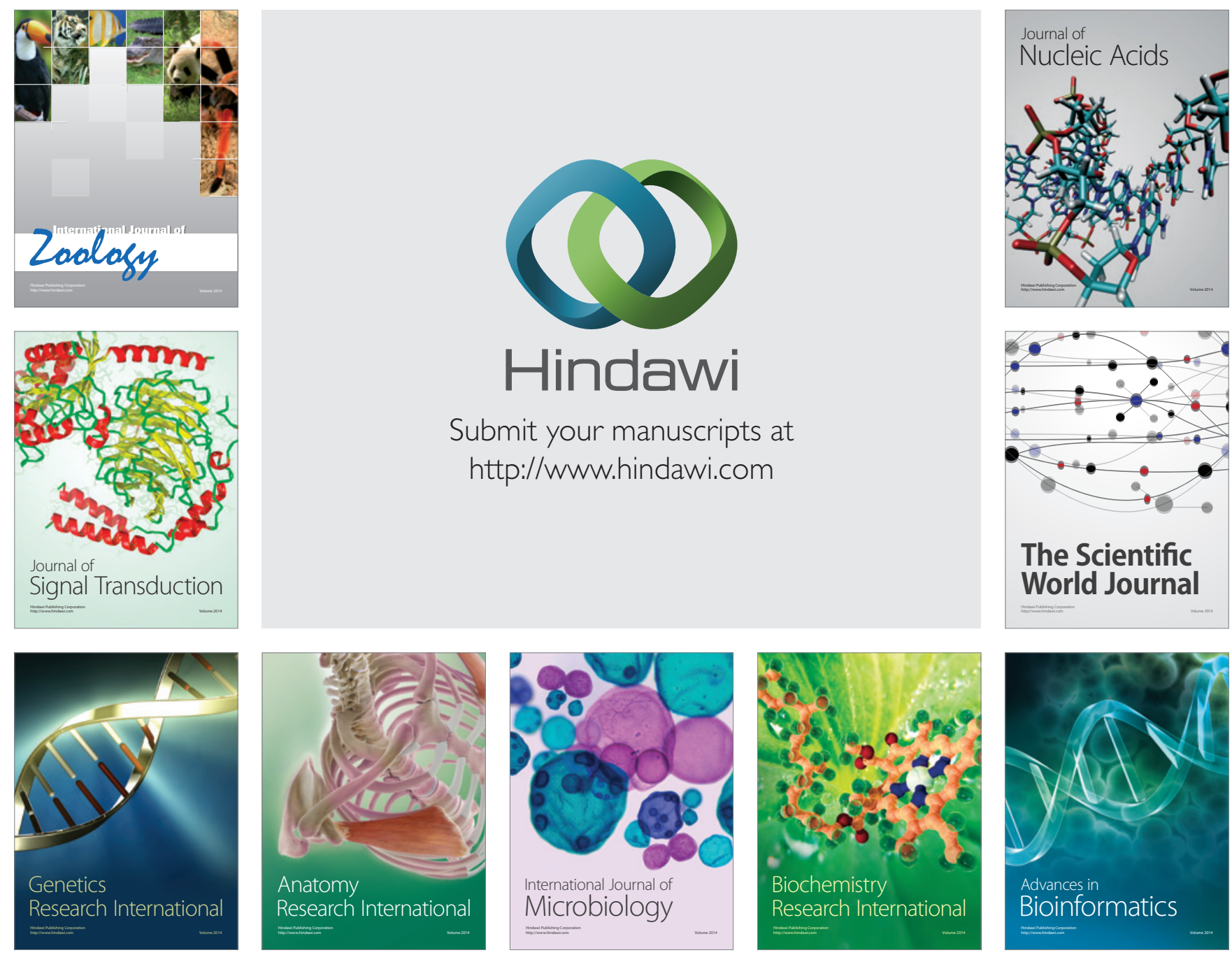

The Scientific World Journal
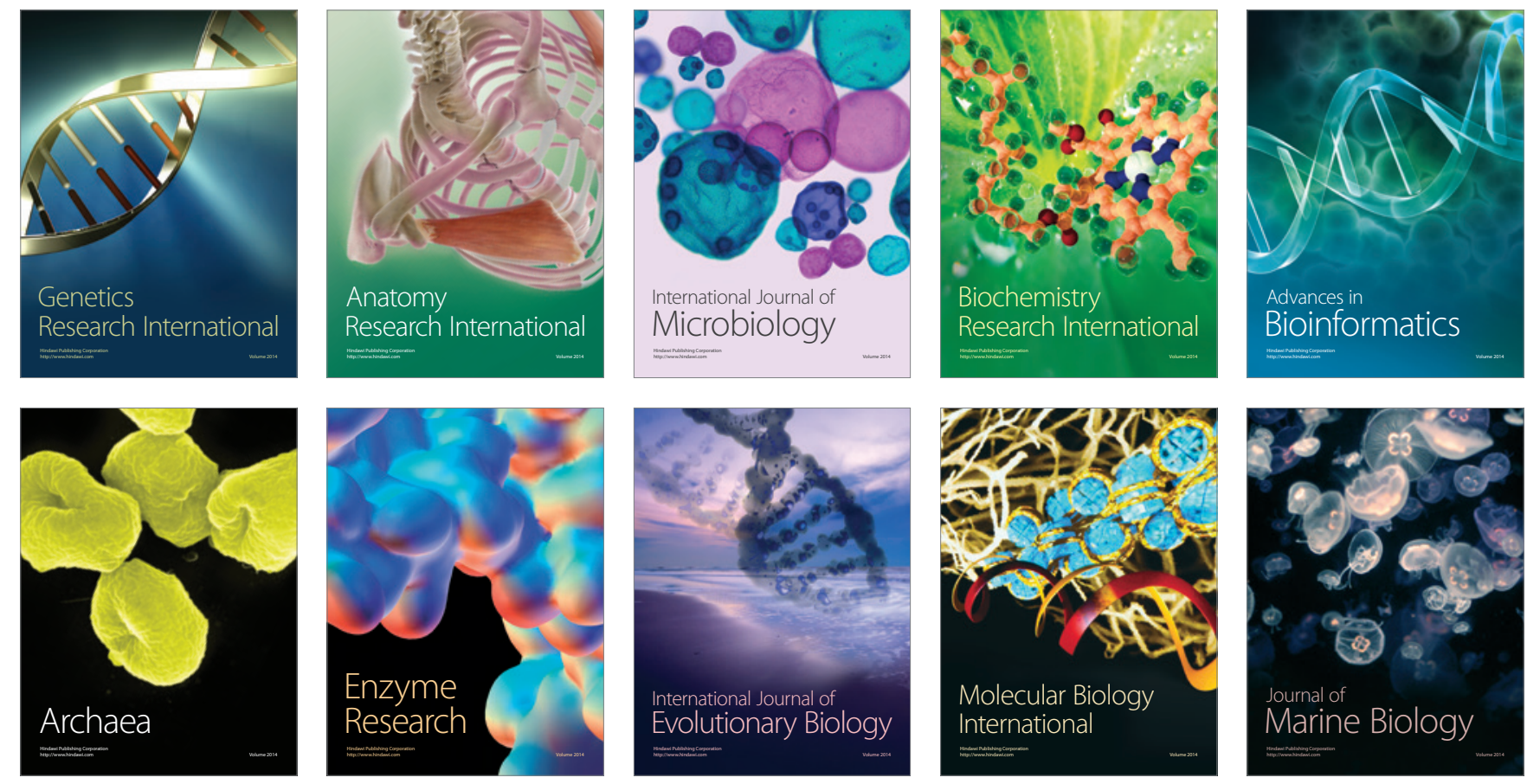